\title{
THE RESULTS OF THE SETTLEMENT OROSHAYEMOYE STUDY IN 2018
}

(C) 2018

Vybornov Alexander Alekseevich, doctor of historical sciences, professor, head of Domestic History and Archeology Department

Vasilyeva Irina Nikolaevna, candidate of historical sciences, senior researcher of Research Department

Doga Natalya Sergeevna, postgraduate student of Domestic History and Archeology Department

Roslyakova Natalya Valerievna, candidate of historical sciences, senior researcher of Archaeological Laboratory Samara State University of Social Sciences and Education (Samara, Russian Federation)

Kosintsev Pavel Andreevich, candidate of biological sciences, senior researcher of Paleoecology Laboratory Institute of Plant and Animal Ecology of Ural Branch of the Russian Academy of Sciences (Yekaterinburg, Russian Federation)

Kulkova Marianna Alekseevna, candidate of geological and mineralogical sciences, associate professor of Geology and Geoecology Department Herzen State Pedagogical University of Russia (Saint Petersburg, Russian Federation)

Popov Alexander Sergeevich, postgraduate student of Domestic History and Archeology Department Samara State University of Social Sciences and Education (Samara, Russian Federation)

Yudin Alexander Ivanovich, doctor of historical sciences, deputy director for scientific work Research Center for the Preservation of Cultural Heritage (Saratov, Russian Federation)

Oinonen Markku, PhD, professor, head of Radiocarbon Laboratory University of Helsinki (Helsinki, Republic of Finland)

Possnert Göran, PhD, professor, head of Radiocarbon Laboratory University of Uppsala (Uppsala, Kingdom of Sweden)

Streltsov Mikhail Alexandrovich, master student of Geology and Geoecology Department Herzen State Pedagogical University of Russia (Saint Petersburg, Russian Federation)

\footnotetext{
Abstract. An essential aspect of studying the Neolithic is the identification of its early phase. The research is constrained by scarce source base of the study. Until recently, the early Neolithic in the Lower Volga region has not been identified by the experts. The situation has changed due to the excavation of the settlement Oroshayemoye I on the river B. Uzen. This paper focuses on the received materials. The monument is multi-layered. During the field work in 2018, the lower cultural layer was investigated. Ceramic, stone and osteological equipment was found in it. The pottery and set of tools are typologically similar to the materials of the lower layer of the Varfolomeyevskaya site, which belong to the Orlovskaya culture. The technological analysis of the ceramics of the Oroshayemoye settlement showed its proximity to the pottery making technology of Orlovskaya culture. The study of osteological remains revealed the presence of bones of aurochs, saiga, tarpan and other wild species on the monument, as well as a domestic dog. According to radiocarbon analysis, the age of the lower layer of the monument is determined by the last quarter of VII - the beginning of the VI millennium BC. Paleoclimatic studies conducted on the monument showed that during this period the climate was warm and humid.

Keywords: Lower Volga region; Oroshayemoye; Neolithic; Orlovskaya culture; stratigraphy; ceramics; stone tools; osteological remains; wild animals; radiocarbon analysis; technological analysis of pottery; A.A. Bobrinsky's methodology; Varfolomeyevskaya site.
}

\section{АНТРОПОЛОГИЧЕСКИЙ АСПЕКТ ОБЫЧАЯ ИСКУССТВЕННОЙ ДЕФОРМАЦИИ ЧЕРЕПА У НАСЕЛЕНИЯ ЭПОХИ СРЕДНЕЙ БРОНЗЫ НИЖНЕГО ПОВОЛЖЬЯ И СОПРЕДЕЛЬНЫХ ТЕРРИТОРИЙ}

Балабанова Мария Афанасьевна, доктор исторических наук, профессор кафедры отечественной и всеобщей истории, археологии Волгоградский государственный университет (2. Волгоград, Российская Федерация)

Аннотация. В данной статье рассматривается антропологический аспект обычая искусственной деформации головы, который практиковали племена катакомбной культурно-исторической общности эпохи средней бронзы Нижнего Поволжья и сопредельных территорий. Для изучения данного культурного феномена, следы которого отражаются на черепе, использовалась краниологическая серия, насчитывающая 207 черепов. На 81 черепе были зафиксированы следы деформации, что составляет $35,2 \%$ от общей численности выборки. В среднем по отдельным могильникам катакомбной культуры Волгоградской области доля деформированных черепов составляет около $17,0 \%$, но имеются могильники, в краниологических сериях которых отсутствуют черепа с деформацией. Тип деформации определяется как кольцевой и лобно-затылочный. Анализ антропологических работ отечественных и зарубежной авторов, а также письменных источников позволяет согласиться с концепцией, высказанной А.В. Шевченко, что обычай деформации черепа в среду племен катакомбной культурно-исторической общности проник через переднеазиатские культурные центры. Сопоставление 
серий деформированных и недеформированных черепов показало, что в основном только признаки мозговой коробки претерпевают изменение под влиянием деформирующей конструкции. Эффект воздействия деформирующей конструкции на лицевые признаки выражен очень слабо. После завершения процесса давления череп приобретает башенную форму или же форму высокого конуса.

Ключевые слова: катакомбная культурно-историческая общность; преднамеренная искусственная деформация черепа; башенный тип; лобно-затылочный тип деформации; серия; краниологические признаки; Волго-Донское междуречье; Калмыкия; Нижний Дон; морфологический комплекс; переднеазиатский культурный центр.

\section{Введение}

В результате археологических раскопок на юге Восточной Европы был получен массовый краниологический материал со следами деформации, происходящий из погребений эпохи средней бронзы, которые археологи относят к различным вариантам катакомбной культуры. Специальному изучению этого обычая у населения эпохи средней бронзы посвящено немного работ, и они носят традиционный характер. В них ставились задачи, касающиеся индивидуальной характеристики черепов, распространения и происхождения обычая деформации, биологическим особенностям населения, практиковавшего его. Выводы, к которым пришли исследователи, во многом сходятся, а суммируя их, можно выделить основные особенности населения эпохи средней бронзы Восточно-Европейских степей, практиковавшего обычай деформации. Так, анализ внутригрупповой структуры краниологических серий показал их полиморфность $[1$, с. $183-185 ; 2$, с. $51 ; 3$, с. $80 ; 4$, с. 48 , $49 ; 5$, с. 12,$13 ; 6$, с. 83, 88]. Формообразующий эффект деформирующей конструкции связан с искажением только признаков мозгового отдела без значительных влияний на лицевой отдел. Различия, которые наблюдаются по комплексу лицевых признаков, могут быть размерными, так как черепа со следами деформации разных локальных групп обладают большей или меньшей массивностью, нежели без деформации $[1$, c. $184 ; 2$, с. $51 ; 3$, с. $80 ; 7$, c. $28 ; 4$, c. $47 ; 6$, с. 89].

Тип деформации на черепах катакомбной культурно-исторической общности (далее - ККИО) определяется как лобно-затылочный и кольцевой. Кольцевой, или циркулярный, тип приобретает конусовидную и башнеобразную формы $[1$, с. $178-185 ; 2$, с. $51 ; 6$, с. $83 ; 8$, с. 10$]$.

Кроме традиционных краниологических исследований, Е.В. Перерва [8, с. 12, 13] проводил анализ патологического состояния группы деформированных черепов из могильников Волгоградской области. Серия из 13 черепов была изучена рентгенологическим и макроскопическим методами. В результате исследования было выяснено, что обычай деформации вполне совместим с нормальной жизнедеятельностью человека. Деформирующий эффект конструкции в детском возрасте мог приводить к развитию синдрома внутричерепной гипертензии, а также возникновению проблем с облитерацией черепных швов. Автору также удалось установить, что на деформированных черепах эпохи средней бронзы высокий процент бытового и боевого травматизма, а также наличие экзостозов в ушном канале. Наличие на деформированных черепах этих патологических состояний позволяет автору предположить социальную значимость обычая преднамеренной искусственной деформации головы [8, с. 16].

В своем исследовании А.В. Шевченко [1, с. 185] решает и вопрос, откуда проник обычай деформации на юг Восточной Европы. Так как обычай преднаме- ренной деформации головы практиковали в эпоху энеолита-бронзы переднеазиатские земледельческие племена, то данный культурный импульс он связывает с этими центрами.

Кроме Волго-Уральского региона обычай деформации практиковали и катакомбные племена Северского Донца, антропологический материал из могильников этого региона изучала Е.А. Шепель [9, c. 52, 53]. В исследуемой ею группе очень большая доля деформированных черепов - 60,0\%, что значительно выше, чем в других регионах. Она также отмечает значительную внутригрупповую изменчивость обеих серий. Деформация на исследуемых Е.А. Шепель черепах представлена разными типами и видами и фиксируется на всех этапах существования ККИО, но наиболее часто встречается в погребениях бахмутского периода. По ее мнению, устойчивость обычая во времени является своеобразием исследуемого региона. Приведенные позднее краниологические измерения по сериям недеформированных и деформированных черепов катакомбной культуры Северского Донца это предположение подтвердили [10, с. 11].

Материалы с территории Среднего Дона изучали В.П. Алексеев [11, с. 187] и М.В. Добровольская [12, c. 44]. В этих сериях также высока доля деформированных черепов: 71,0\% и 64,3\%. Тип деформации кольцевой с деформирующей повязкой, которая накладывалась на уровне лобных бугров и верхних выйных линий.

Вопросу распространения обычая искусственной деформации на материалах могильников Нижнего Дона эпохи средней бронзы посвящена статья Е.Ф. Батиевой [7, с. 27, 33]. Ею исследован массовый материал, насчитывающий 1207 черепов на 297, из которых были отмечены следы преднамеренной искусственной деформации. В среднем же доля деформированных черепов около 25,0\%. По полу и возрасту доля деформированных черепов распределяются следующим образом: 26,5\% - на мужских; 27,9\% на женских и 20,0\% - на детских черепах. Частота встречаемости искусственно деформированных черепов по могильникам Нижнего Дона сильно различается - от отсутствия их до 100,0\%. Кроме этого, автор отмечает, что в могильниках Правобережья Дона частота встречаемости деформации несколько выше, чем в Левобережье (26,5\% и 22,2\%). Сравнение серии деформированных и недеформированных черепов позволило Е.Ф. Батиевой [7, с. 28] отметить различия, которые, на ее взгляд, не ограничиваются только теми признаками, на которые могла влиять деформация. Деформированные черепа - с меньшими размерами, с менее выступающим носом и лицевыми пропорциями. У них относительно шире лицо и уже нос.

Подводя итоги вышесказанному, следует отметить, что практически все изученные локально-территориальные группы эпохи средней бронзы юга Восточной Европы, известные как ККИО, практиковавшая обычай искусственной деформации, имеют похожие характеристики как по культурному признаку (искусственно измеренный череп и его тип), так и по 
биологическим признакам (морфологическая неоднородность, влияние деформирующей конструкции на изменение краниометрических признаков и т.п.).

Таким образом, анализ исследований и публикаций, в которых рассматривались различные аспекты проблемы искусственно деформированных черепов катакомбной культурно-исторической общности, а также накопление новых материалов и суммирование их с опубликованными позволяет автору данной публикации более детально рассмотреть данную проблему с позиций массового материала.

\section{Материал и методика исследования}

Материалом данного исследования явилась суммарная серия опубликованных черепов и вновь вводимых в научный оборот с локализацией могильников:

1) по террасам Есауловского Аксая и Мышковы (Аксай I и III; Абганерово III и V; Первомайский I, VII и VIII и др.);

2) Задонье (Орешкин I; Перекопка и др.);

3) террасы реки Иловли (Авиловский II, Кондраши, Бердия, Ольховка, Петрунино II, Качалин и др.);

4) территория Калмыкии (Островной, Малые Дербеты I и II, Ергенинский I и др.);

5) опубликованные серии по Калмыкии [13; 14];

6) опубликованные серии по Заволжью [14; 15].

Серия по катакомбной культуре насчитывает 207 черепов: без деформации - 126; со следами деформации - 81 череп, что составляет $35,2 \%$ от общей численности выборки.

В процессе выделения комплекса деформации, то есть краниологических признаков, находящихся под действием моделирующего эффекта деформирующей конструкции в периоде роста и развития черепа, сначала сопоставлялись методом статистической проверки гипотез по t-критерию Стьюдента суммарные серии деформированных и недеформированных черепов, а затем серии восточноманычского и среднедонского вариантов ККИО.

\section{Результаты исследований и их обсуждение}

Как выше отмечалось, доля деформированных черепов в суммарной серии катакомбной культуры составляет $35,2 \%$ от общей численности выборки. Что касается частоты встречаемости деформированных черепов в различных могильниках Нижнего Поволжья, то они отсутствуют в могильниках Ольховка, Петрунино II, Перегрузное I и др. и до 50,0\% случаев встречаются в могильниках Орешкин I, Кондраши и др.). Наибольшее их количество в могильниках Волго-Донского междуречья с максимальной долей деформированных черепов - около 30,0\% (могильники Авиловский II, Абганерово III, Котлубань и др.). В среднем же по суммарной серии катакомбной культуры Нижнего Поволжья с учетом черепов плохой сохранности не включенных в краниологический анализ, а также детских черепов доля деформированных черепов составляет около $17,0 \%$.

Типологические определения в различных сериях Нижнего Поволжья позволяют выделить наиболее часто встречающиеся варианты деформации, к ним относится кольцевой или циркулярный тип $[16$, c. 82-84]. На отдельных черепах он очень часто находится в сочетании с лобно-затылочным типом. Такая форма приобретается, когда кроме деформирующей циркулярной повязки имеются дополнительные плоские приспособления (дощечки), которые накладываются на лобную и затылочную части. На черепах эпохи средней бронзы кольцевой тип ча- ще всего приобретает башенную форму, в отличие от материалов первых веков нашей эры - там скошенный конус. При этом конусовидный также встречается, а его угол может сильно варьироваться от незначительного до большого. При сходстве типов деформации на черепах катакомбной и позднесарматской культур визуально они резко отличаются. Эти различия хорошо видны на фотографиях черепов (рис. 1, 2).

В настоящее время нет причин полагать, что практика деформации у народов, использовавших этот обычай, сильно различалась. По крайней мере данные письменных источников и описание практики деформации у коренных австралийцев, африканцев, американцев, хорезмийцев и у других народов свидетельствуют о том, что для деформации использовались следующие приемы: массаж головы младенца; специальные приспособления в виде повязок, шапочек или сложные, чаще деревянные конструкций и т.д. $[17$, фр. $14 ; 18$, кн. XI. $8 ; 19$, с. $186 ; 20$, c. $420 ; 21$, V. 8 ; VIII. 9; 22, c. 19, 20, 30, 187, 188; 23 , c. $43 ; 24$, c. $385 ; 414,415 ; 25$, c. $171 ; 26$, p. $63-70 ; 27$, p. 242,$243 ; 28$, p. 70,71 и др.].

Серия деформированных детских черепов катакомбной культуры из могильников Майоровский; Абганерово V; Авиловский II, Евстратовский и др., а также фотографии и рисунки африканских и американских детей (рис. 3: 1-5) позволяют реконструировать действие деформирующей конструкции на голову ребенка и проследить этот процесс. Так, у младенцев из погребения могильника Майоровский, а также у африканских и американских детей к полугодовалому возрасту практически уже достигнута нужная форма черепа, с типом деформации, характерной для племени макбету и народа чинук (рис. 3: $1,4,5)[29 ; 30]$. Такой быстрый результат формообразования головы под давлением деформирующей конструкции зафиксирован и многими исследователями. Черепа детей более старшего возраста, 2-6 лет, демонстрируют еще больший эффект деформации (рис. 3: 2, 3). Степень деформации на взрослых черепах, особенно группы из Волго-Донского междуречья, слабее, чем у детей. Видимо, после снятия деформирующего устройства череп, продолжая расти, несколько компенсирует эффект деформации, частично возвращаясь к генетически запрограммированным нормам (рис. 1: 1-3; рис. 2: 1, 2). Сила, с которой конструкция давит на отдельные части черепа, иногда приводит к нарушению сроков облитерации швов. На деформированных материалах из Нижнего Поволжья наблюдаются как случаи опережения сроков облитерации, так и запаздывания, что показали исследования Е.В. Перервы [8, с. 13] и наш материал (рис. 1: 2). У вышеописанного младенца из могильника Майоровский под давлением деформирующих бандажей нарушены сроки облитерации родничков. Если задний затылочный родничок закрылся в срок, к 2-3 месяцам, то зарастание сосцевидных родничков запаздывает [31, с. 150]. Следует отметить, что на деформированных детских черепах встречаются случаи облитерации всех родничков уже к 1-1,5 годам. Нарушение сроков облитерации черепных швов и младенческих родничков, без сомнения, связано с увеличением частоты встречаемости метопизма и дополнительных косточек (рис. 3: 2). Эта проблема требует дополнительного исследования, а в связи с тем, что материал эпохи средней бронзы плохой сохранности, сложно изучить его по программам краниоскопических признаков. 

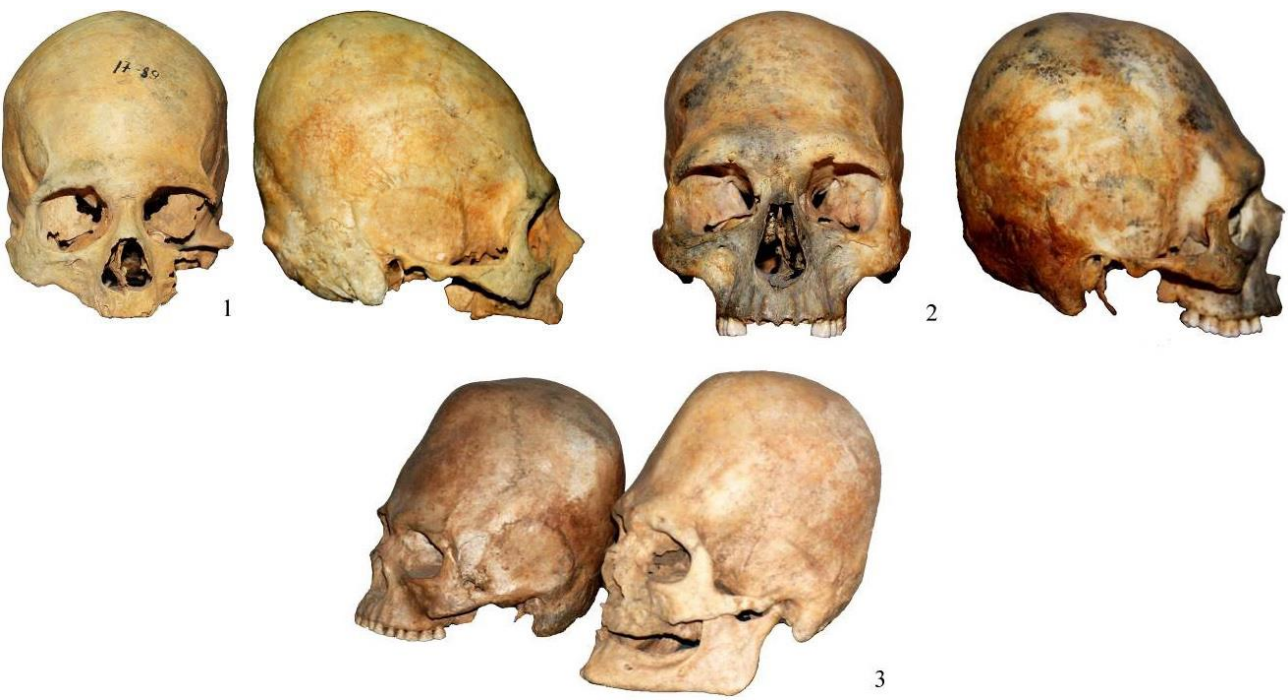

Рисунок 1 - Обычай искусственной деформации на черепах эпохи средней бронзы.

1 - череп мужчины (старше 50 лет) из погребения 9 кургана 1 могильника Первомайский VII

(Инв. № 17-89: ВолГУ); 2- череп мужчины (20-30 лет) из погребения 8 кургана 32 могильника Авиловский II (Инв. № 2-59: ВолГУ); 3- череп мужчины (25-30 лет) из погребения 16 кургана 9 могильника Тузлуки (на фото слева) и череп мужчины (старше 50 лет) из погребения 39 кургана 4 могильника Золотые Горки (на фото справа) (Кол. АИА и ПМ-З)
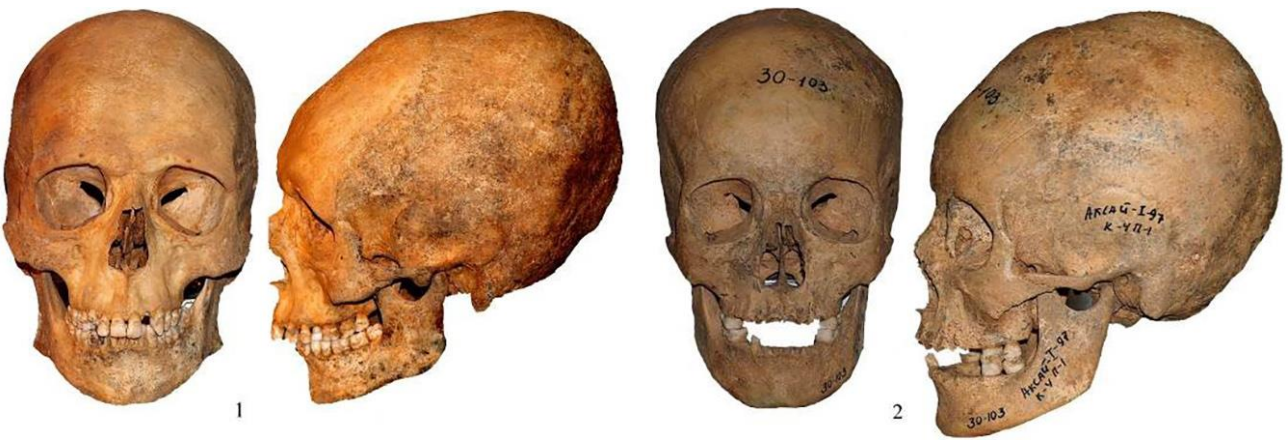

Рисунок 2 - Обычай искусственной деформации на черепах эпохи позднесарматского времени. 1 - череп мужчины (20-25 лет) из кургана 6 могильника Ковыльнов III, (Инв. № 160-5: ВолГУ); 2 - череп женщины (14-16 лет) из кургана 4 могильника Аксай I, (Инв. № 30-103: ВолГУ)
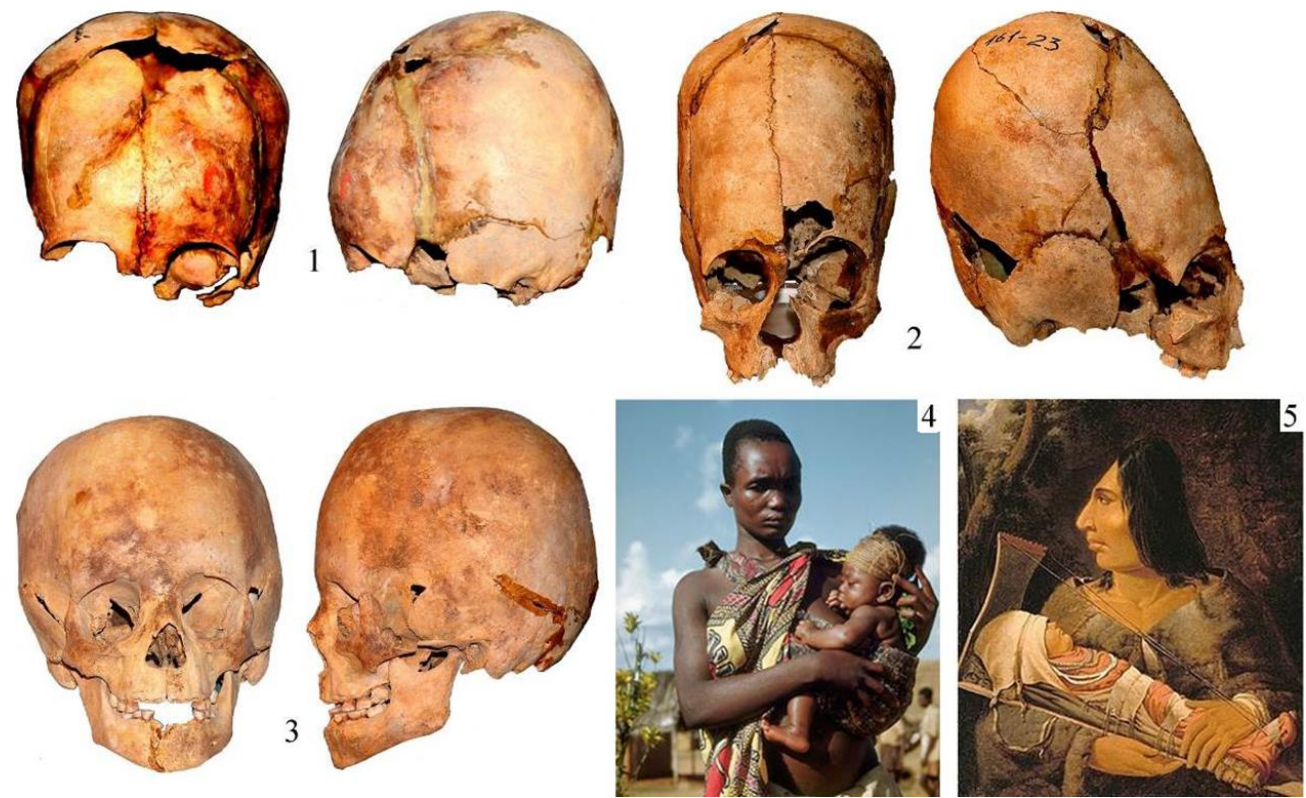

Рисунок 3 - Детские черепа ККИО со следами искусственной деформации и обычай искусственной деформации черепа у народов чинук и мангбету.

1 - череп ребенка (6 мес. - 1 год) из погребения 8 кургана 1 могильника Майоровский (Инв. № 50-5: ВолГУ); 2 - череп ребенка (6-6,5 лет) из погребения 1 одиночного кургана могильника Тихоновка (Инв. № 161-23: ВолГУ); 3- череп ребенка (6-7 лет) из погребения 3 кургана 1 могильника Евстратовский I, (Инв. № 164-1: ВолГУ); 4- фото женщины с ребенком племени мангбету; 5- картина Пола Кейна, на которой

изображена женщина с деформированной головой и ребенок племени чинук с деформирующей конструкцией 
С проблемой роста и развития черепа, находящегося под прессингом деформирующей конструкции, связана проблема ее влияния на краниометрические признаки, для решения которой проводилось сопоставление деформированных и недеформированных черепов катакомбной культуры. Комплекс деформации, то есть набор признаков, претерпевающих изменение под давлением деформирующей конструкции, выявлялся методом статистической проверки гипотез, основанным на распределении t-критерия Стьюдента. Результаты сопоставления показали статистически достоверно значимые различия между тремя мужскими группами (суммарные, восточноманычские и среднедонские группы) деформированных и недеформированных черепов по 35; 17 и 10 признакам из 72 включенных в сравнительный анализ (табл. 1). Набор признаков один и тот же и описывает изменчивость, главным образом, мозговой коробки. Меньшее количество признаков с достоверно значимыми различиями при сравнении второй и третьей групп можно объяснить их меньшей численностью, а также отсутствуем в публикации по восточноманычскому варианту таких признаков, как высота изгиба лба и затылка, а также индексы и углы, вычисленные на их основе [13, с. 235-267] (табл. 1). Из лицевых признаков только небольшая их часть имеет достоверно значимые различия, и они отражают изменчивость при сравнении в основном суммарных серий. К набору признаков лицевого скелета относятся скуловой диаметр (45), высота орбиты (52) и ее указатель (52:51), высота носа (55), симотический (SS:SC) и дакриальный (DS:DC) указатели, назомалярный угол (77), общий лицевой угол (72), угол профиля (75) и угол выступания носа (75-1) и др. Рассмотрим подробно комплекс признаков со статистически значимыми различиями.

Результаты сравнения позволяют поддержать концепцию о том, что при катакомбном типе деформации моделирующий эффект преимущественно направлен на мозговую коробку (рис. 4: 1-3). Изменения сильнее всего затрагивают продольный, поперечный и высотный диаметры и их производные, а также лобную и затылочную кости, так как именно они находятся под усиленным давлением деформирующей конструкции. В результате деформации продольный диаметр демонстрирует укорочение, поперечный - сужение, а высотные (17 и 20) - повышение. Часть признаков: высотно-продольный и высотно-поперечный указатели, общеростовая величина, условное трансверсальное сечение и условный трансверсальный объем (17:1; 17:8; ОРВ; М2; М3), вычисленные на основе трех тотальных размеров, - также имеют достоверно значимые различия. При этом существенные различия по общеростовой величине и условному трансверсальному объему, возможно, связаны не только эффектом деформации, но и с большей массивностью всех серий недеформированных черепов по сравнению с деформированными. Все три группы демонстрируют один и тот же результат, как и группы деформированных и недеформированных черепов из могильников Нижнего Дона, о чем писала Е.Ф. Батиева [7, с. 28]. Эти тенденции на материалах эпохи средней бронзы отличаются от результатов сравнения деформированных и недеформированных черепов позднесарматского времени [32, с. 174].
Здесь общеростовая величина и условный трансверсальный объем отличаются незначительно и статистически не достоверно, а по признаку условное трансверсальное сечение группы имеют достоверно значимые различия. Это и понятно, так как при вычислении его используют два признака: продольный и поперечный диаметры, которые испытывают на себе влияние деформирующей конструкции по направлению уменьшения их по сравнению с генетически запрограммированными размерами. Объем же мозговой коробки остается в норме, так как компенсирует лишения по своей длине и ширине за счет увеличения высоты.

Совсем по-другому выглядит ситуация при сравнении деформированных и недеформированных черепов катакомбной культуры, о чем выше отмечалось. Поэтому вывод о существенных морфологических различиях, связанных не только с влиянием на размерные признаки деформирующей конструкции, но и с большей массивностью группы недеформированных черепов ККИО, становится вполне резонным. В связи с этим можно предположить, что часть общества, практиковавшая обычай преднамеренной деформации черепа, морфологически отличалась от той части, которая не практиковала его.

Что касается деформирующего эффекта на лобную и затылочную кости, то, по-видимому, их хорды существенно удлиняются, а дуги несколько укорачиваются. Статистически значимые различия дает только длина хорд. Изменения, которые затрагивают теменную кость, приводят к укорочению ее хорды и удлинению дуги, но статистически значимые изменения только по длине дуги. В соответствии с этими изменениями указатели изгиба лба и затылка больше на деформированных черепах, а указатель изгиба темени больше на недеформированных черепах (рис. 3: 1-3). Кроме изменения длин дуг и хорд, происходит уплощение лобной и затылочной костей, а высота их изгиба снижается. Индексы и углы, вычисленные на их основе, свидетельствуют об этих изменениях: индексы выпуклости меньше, а углы значительно больше на деформированных черепах. В вертикальном профиле лоб приобретает покатую форму (табл. 1). Все вышеперечисленные признаки при сравнении дают статистически значимые и высоко значимые различия, уровень 0,01 и 0,001 .

Наблюдаемые тенденция к повышению некоторых высотных лицевых признаков на деформированных черепах также требуют объяснения и доработки. В этом направлении уже осуществляются исследования. Так, А.А. Казарницкий, изучивший объемный материал по материалам могильников Калмыкии, показал, что моделирующий эффект деформации распространяется и на лицевой комплекс [5, с. 22]. По мнению автора, возможные объяснения для наблюдаемых различий можно найти в неоднозначности классификаций типов деформации, в морфотипических различиях исследуемого населения и в точности установления деформированных и недеформированных черепов в сериях. В этом отношении можно сослаться и на исследования американских ученых, которые считают, что при лобно-затылочном типе деформации эффект изменений подчеркивает морфологические направления, уже существующие у населения, которое практикует преднамеренную деформацию [33, p. 21 и др.]. 
Таблица 1 - Значимые различия краниологических признаков при сравнении мужских серий ККИО

\begin{tabular}{|c|c|c|c|c|c|c|c|}
\hline \multicolumn{8}{|c|}{ Суммарные серии } \\
\hline \multirow{2}{*}{ №№ по Мартину и др. } & \multicolumn{3}{|c|}{ с деформацией } & \multicolumn{3}{|c|}{ без деформации } & \multirow{2}{*}{ значимость } \\
\hline & $\mathrm{n}$ & $\mathrm{X}$ & $\mathrm{s}$ & $\mathrm{n}$ & $\bar{X}$ & $\mathrm{~s}$ & \\
\hline 1. Продольный диаметр & 43 & 180,5 & 8,0 & 79 & 188,9 & 7,6 & $p<0,001$ \\
\hline 8. Поперечный диаметр & 39 & 137,0 & 5,6 & 79 & 141,4 & 8,0 & $p<0,001$ \\
\hline 17. Высотный диаметр & 23 & 146,1 & 6,3 & 54 & 138,5 & 5,4 & $p<0,001$ \\
\hline 17:1. Высотно-продольный указатель & 23 & 82,1 & 5,2 & 54 & 73,8 & 4,0 & $p<0,001$ \\
\hline 17:8. Высотно-поперечный указатель & 23 & 107,4 & 5,8 & 54 & 98,0 & 7,5 & $p<0,001$ \\
\hline ОРВ. Общеростовая величина & 23 & 267,9 & 7,3 & 54 & 273,3 & 6,0 & $p<0,001$ \\
\hline М2. Условное трансверсальное сечение & 38 & 246,5 & 14,9 & 78 & 266,5 & 15,4 & $p<0,001$ \\
\hline М3. Условный трансверсальный объем & 23 & 1774,6 & 135,4 & 54 & 1844,0 & 121,4 & $p<0,001$ \\
\hline 20. Ушная высота & 29 & 124,3 & 5,8 & 59 & 118,3 & 5,2 & $p<0,001$ \\
\hline 10. Наибольшая ширина лба & 38 & 115,1 & 5,6 & 74 & 118,1 & 7,7 & $p<0,01$ \\
\hline 11. Ширина основания & 31 & 123,8 & 7,7 & 60 & 126,8 & 6,5 & $p<0,01$ \\
\hline 12. Ширина затылка & 35 & 107,1 & 6,8 & 63 & 112,8 & 5,6 & $p<0,001$ \\
\hline 29. Лобная хорда & 42 & 117,2 & 6,7 & 71 & 113,2 & 5,1 & $p<0,01$ \\
\hline 27. Теменная дуга & 41 & 129,1 & 7,6 & 70 & 126,6 & 5,8 & $p<0,05$ \\
\hline 28. Затылочная дуга & 35 & 113,6 & 6,0 & 61 & 116,0 & 6,6 & $p<0,05$ \\
\hline 29:26. Указатель изгиба лба & 42 & 92,4 & 3,2 & 70 & 89,1 & 2,1 & $p<0,05$ \\
\hline 30:27. Указатель изгиба темени & 41 & 87,0 & 2,9 & 70 & 89,9 & 2,5 & $p<0,05$ \\
\hline 31:29. Указатель изгиба затылка & 35 & 86,9 & 2,6 & 61 & 83,0 & 3,7 & $p<0,05$ \\
\hline Syb.N $\beta$. Высота изгиба лба & 31 & 17,9 & 3,8 & 51 & 23,9 & 2,7 & $p<0,001$ \\
\hline Индекс изгиба лба & 31 & 15,4 & 3,5 & 51 & 21,1 & 2,3 & $p<0,001$ \\
\hline УИЛ. Угол изгиба лба & 31 & 145,8 & 7,2 & 50 & 134,2 & 4,7 & $p<0,001$ \\
\hline 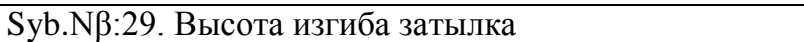 & 28 & 21,5 & 3,7 & 42 & 26,7 & 3,3 & $p<0,001$ \\
\hline Индекс изгиба затылка & 28 & 21,8 & 3,7 & 41 & 28,5 & 3,5 & $p<0,001$ \\
\hline УИЗ. Угол изгиба затылка & 28 & 133,5 & 7,5 & 41 & 121,1 & 6,6 & $p<0,001$ \\
\hline 45. Скуловой диаметр & 34 & 135,1 & 6,5 & 59 & 137,7 & 5,7 & $p<0,05$ \\
\hline 48:17. Вертикальный фацио-церебральный указатель & 23 & 48,6 & 4,2 & 50 & 51,5 & 3,0 & $p<0,05$ \\
\hline 52:51. Орбитный указатель & 36 & 77,0 & 7,2 & 69 & 73,9 & 5,2 & $p<0,05$ \\
\hline 77. Назомалярный угол & 39 & 134,7 & 4,9 & 71 & 137,3 & 6,3 & $p<0,05$ \\
\hline SS:SC. Симотический указатель & 32 & 56,8 & 14,3 & 61 & 61,5 & 13,8 & $p<0,01$ \\
\hline DS:DC. Дакриальный указатель & 27 & 61,1 & 12,8 & 42 & 64,1 & 9,6 & $p<0,05$ \\
\hline 32. Угол лба назион-метопион & 32 & 76 & 6,6 & 50 & 80,4 & 5,5 & $p<0,01$ \\
\hline Угол лба от глабеллы & 24 & 69,6 & 7,5 & 30 & 73,3 & 7,0 & $p<0,01$ \\
\hline
\end{tabular}

№№ по Мартину и др.

1. Продольный диаметр

8. Поперечный диаметр

17. Высотный диаметр

17:1. Высотно-продольный указатель

17:8. Высотно-поперечный указатель

с деформацией $\quad$ без деформации

М2. Условное трансверсальное сечение

\begin{tabular}{c|c|c|c|c|c|c}
\multicolumn{2}{c|}{ с деформацией } & \multicolumn{2}{c}{ без деформации } & \multirow{2}{*}{ значимость } \\
\cline { 1 - 4 } $\mathrm{n}$ & $\mathrm{X}$ & $\mathrm{s}$ & $\mathrm{n}$ & $\mathrm{X}$ & $\mathrm{s}$ & \\
\hline 16 & 183,6 & 7,8 & 23 & 190,9 & 7,9 & $p<0,01$ \\
\hline 16 & 136,2 & 5,9 & 22 & 141,6 & 9,3 & $p<0,05$ \\
\hline 9 & 144,7 & 4,4 & 16 & 138,7 & 4,1 & $p<0,001$ \\
9 & 79,6 & 2,5 & 16 & 73,7 & 3,4 & $p<0,001$ \\
\hline 9 & 106,2 & 4,4 & 16 & 97,3 & 8,0 & $p<0,01$ \\
\hline 16 & 250,0 & 13,4 & 22 & 269,3 & 16,8 & $p<0,001$ \\
10 & 125,8 & 6,4 & 18 & 118,8 & 4,8 & $p<0,01$ \\
11 & 120,6 & 7,8 & 19 & 126,1 & 6,4 & $p<0,05$ \\
12 & 107,3 & 9,0 & 21 & 113,3 & 5,6 & $p<0,05$ \\
\hline 17 & 119,7 & 6,5 & 22 & 113,5 & 4,2 & $p<0,001$ \\
\hline 12 & 87,7 & 6,6 & 21 & 93,2 & 7,6 & $p<0,05$ \\
\hline 17 & 91,9 & 2,6 & 21 & 89,2 & 2,7 & $p<0,01$ \\
\hline 16 & 87,6 & 2,3 & 21 & 90,3 & 1,8 & $p<0,001$ \\
12 & 86,8 & 2,6 & 21 & 82,9 & 4,3 & $p<0,01$ \\
16 & 34,6 & 1,6 & 22 & 31,6 & 2,0 & $p<0,001$ \\
14 & 78,4 & 4,9 & 21 & 72,3 & 5,0 & $p<0,001$ \\
\hline 10 & 74,1 & 5,5 & 18 & 81,2 & 6,7 & $p<0,001$ \\
\hline
\end{tabular}

20. Ушная высота

11. Ширина основания

12. Ширина затылка

26. Лобная дуга

28:27. Затылочно-теменной индекс

29:26. Указатель изгиба лба

30:27. Указатель изгиба темени

31:29. Указатель изгиба затылка

52. Высота орбиты

52:51. Орбитный указатель

32. Угол лба назион-метопион

\section{Серии среднедонского варианта ККИО}

№oo по Мартину и др.

1. Продольный диаметр

17:1. Высотно-продольный указатель

М2. Условное трансверсальное сечение

Syb.N $\beta$. Высота изгиба лба

Индекс изгиба лба

УИЛ. Угол изгиба лба

Syb.N $\beta: 29$. Высота изгиба затылка

Индекс изгиба затылка

УИЗ. Угол изгиба затылка

55. Высота носа

\begin{tabular}{|c|c|c|c|c|c|c|}
\multicolumn{3}{c|}{ с деформацией } & \multicolumn{3}{c|}{ без деформации } & значимость \\
\hline 9 & 176,9 & 6,4 & 7 & 190,0 & 5,8 & $p<0,001$ \\
\hline 5 & 84,0 & 3,7 & 3 & 73,7 & 2,6 & $p<0,001$ \\
\hline 8 & 242,9 & 16,0 & 7 & 270,1 & 10,7 & $p<0,001$ \\
9 & 16,4 & 2,4 & 7 & 24,7 & 1,85 & $p<0,001$ \\
\hline 9 & 13,9 & 2,2 & 7 & 22,0 & 2,0 & $p<0,001$ \\
\hline 9 & 148,9 & 4,6 & 7 & 132,5 & 3,9 & $p<0,001$ \\
7 & 19,1 & 2,2 & 3 & 26,2 & 1,8 & $p<0,001$ \\
\hline 7 & 20,2 & 2,1 & 3 & 27,7 & 1,2 & $p<0,001$ \\
\hline 7 & 137,4 & 5,6 & 3 & 122,7 & 2,1 & $p<0,001$ \\
9 & 53,9 & 2,5 & 8 & 50,5 & 2,6 & $p<0,01$ \\
\hline
\end{tabular}



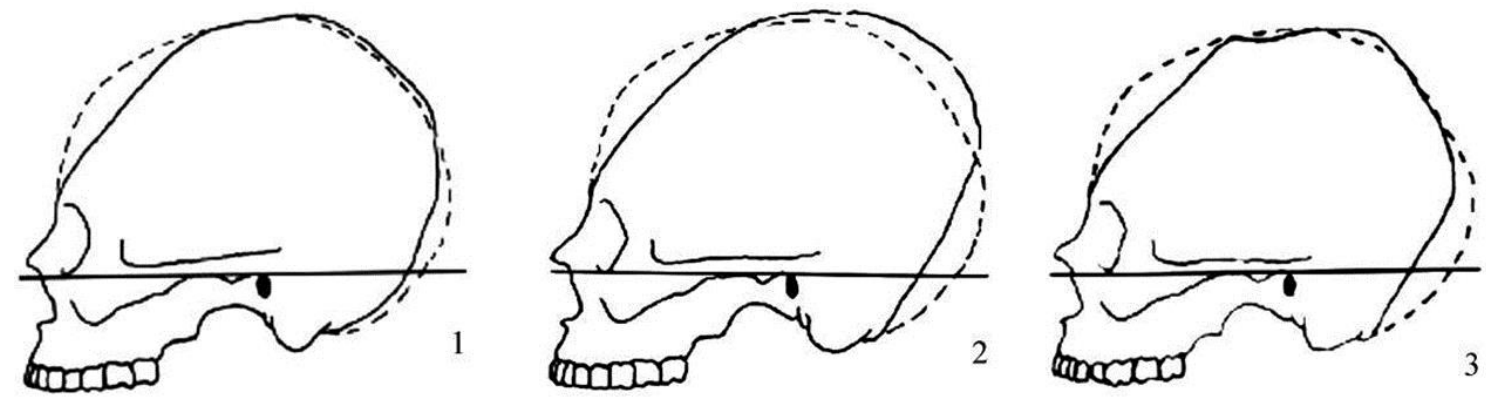

Рисунок 4 - Изменение формы черепа

в результате преднамеренной искусственной деформации катакомбного типа

Вполне можно согласиться с этими исследователями по поводу влияния деформирующей конструкции на лицевые признаки, но, как признавал А.В. Шевченко [1, с. 184], эффект деформации незначительный и, видимо, затрагивает только надглазничную область и переносье. О чем свидетельствуют и результаты нашего исследования. Так, с приемлемой границей статистической значимости различий в суммарных сериях находится скуловой диаметр, который, скорее всего, связан с уже отмеченными общими тенденциями, массивностью серии недеформированных черепов и грацильностью серии деформированных черепов (табл. 1). Наличие различий, отражающих область переносья и носовых костей, а также высоту глазницы (DS:DC; SS:SC; 52:51), можно связать со слабым моделирующим эффектом верхней части лица деформирующей конструкции, которая, видимо, накладывалась широкой лентой на лобную и затылочную кости (рис. 3: 3). В соответствии с этими морфологическими особенностями можно дать реконструкцию деформирующего устройства. Видимо, оно устанавливалось на уровне лобных бугров, слегка затрагивая надглазничную область и переносье. Косвенным свидетельством такого наложения является слабый моделирующий эффект на обе ширины лобной и ширину затылочной костей, они более узкие в деформированных группах (табл. 1). При этом деформирующее устройство было, скорее всего, твердым, так как простое бинтование подручными средствами могло осложнять поддержку повязки на голове (рис. 3). Свой вариант наложения деформирующей повязки на черепах среднедонской катакомбной культуры дает М.В. Добровольская [12, с. 44], считающая, что повязка накладывалась на уровне лобных бугров.

Кроме проблемы морфологических изменений на черепе в процессе практики обычая искусственной деформации, встает вопрос о ее функции. При решении его для населения ККИО нужно учесть прежде всего то, что только часть общества практиковала этот обычай и она обладала морфотипическим своеобразием по сравнению с остальной частью.

Как свидетельствуют данные письменных источников и этнографические материалы, для выделения привилегированной группы людей или отличной от остальной части общества необходимы внешние атрибуты. Та часть общества или же целый народ, которые практиковали обычай искусственной деформации головы, измененную форму головы воспринимали как внешний атрибут и использовали для выделения себя из группы подобных или для противопоставления себя остальной части общества [34, c. 72,$73 ; 35$, с. 75]. Таким образом, искусственно деформированная голова выполняла знаковую функцию. Знаковая функция такой модификации тела, как искусственно измененная форма головы, зафиксирована у многих народов, во всех частях света. Вероятно, она играла ключевую роль в обществе майя, стремившихся получить форму черепа, которая является эстетически более приятной или становится желаемым атрибутом. В связи с этим интересным выглядит разговор между майя и ранним испанским миссионером, который спросил о значении обычая. По данным информатора, у только что родившегося ребенка голова очень пластичная, и ее легко можно отформовать по типу, воспроизводящему форму головы бога, тем самым обеспечивая себе не только связь с ним, но и статус благородных, красивых и лучше приспособленных нести жизненное бремя. Согласно мнению других авторов, основанному на анализе художественных изделий, деформация головы у майя осуществлялась для того, чтобы иметь сходство с головой ягуара, священного животного и символа силы и мощности. Есть сведения и о том, что майя деформировали головы, чтобы иметь сходство с головой бога Маиса, который был символом плодородия [36].

Знаковую функцию модифицированной головы можно предположить в Древнем Египте, так как ее практиковали в семьях фараонов [37]. Социо-дифференцирующее значение, видимо, имел этот обычай и у американских народов салиши и чинук [38, с. 466; 39, с. 627]. Они выделяли себя на фоне рабов деформированной головой.

Есть информация и о практике деформации у инков: чем выше был статус человека, тем сильнее деформация головы. Наибольшей силы деформации достигались у членов императорской семьи, Великих Инка.

Этно-дифференцирующую функцию измененной формы головы у хорезмийцев отмечает аль-Макдиси $[19$, c. 160$]$.

Далеко не полный перечень вышеприведенных источников позволяет определить маркирующее значение измененной формы головы у той части ККИО, которая практиковала этот обычай, а обозначал он социальную или этническую их принадлежность.

\section{Заключение}

Таким образом, характеристика типов деформаций, которые практиковали племена катакомбной культурно-исторической общности Нижнего Поволжья и сопредельных территорий, влияние деформирующего устройства на краниометрические признаки, а также значение этого обычая позволяют под- 
держать некоторые закономерности, выведенные отечественными и зарубежными учеными, а результаты нашего исследования свести к следующим основным выводам:

1) видимо, племена ККИО практиковали смешанный тип деформации, кольцевой с лобно-затылочным, эффект которого достигался широким деформирующим устройством твердой конструкции;

2) данная конструкция позволяла моделировать форму черепа таким образом, что она приобретала форму башни или высокого конуса;

3) различия в деформирующих устройствах в катакомбное и позднесарматское время позволяют визуально легко отличить черепа;

4) при кольцевом типе деформации моделирующий эффект распространяется на изменение как параметров мозгового отдела черепа, так и на лицевые признаки, но, очевидно, результат его гасится лобнозатылочным наложением плоских приспособлений;

5) при лобно-затылочном типе, который, видимо, преобладает на черепах ККИО, результат влияния на лицевые признаки следует признать как статистически мало достоверный;

6) разногласие между исследователями по этому вопросу, видимо, следует отнести к различному типологическому разнообразию серий и суммированию данных по вариантам катакомбной культуры;

7) изучение различных аспектов преднамеренной деформации головы у древних народов Нижнего Поволжья позволяет предположить у них схожие с другими регионами и культурами поведенческие и социокультурные мотивы;

8) анализ источников показал, что для деформации головы использовали сходный подручный материал, а технологическое решение каждый народ, использовавший этот обычай, вырабатывал самостоятельно в процессе длительной культурной традиции;

9) невысокая доля деформированных черепов в сериях эпохи средней бронзы позволяет говорить об элитарности общества, практикующего обычай деформации.

\section{Список литературы:}

1. Шевченко А.В. Антропология населения южнорусских степей в эпоху бронзы // Антропология современного и древнего населения Европейской части СССР. Л.: Наука, 1986. С. 121-215.

2. Хохлов А.А. Черепа с искусственной деформацией эпохи бронзы Волго-Уральского региона // Искусственная деформации головы человека в прошлом Евразии. OPUS: Междисциплинарные исследования в археологии: сб. статей. Вып. 5. М.: Изд-во ИА РАН, 2006. С. 47-52.

3. Хохлов А.А. Морфогенетические процессы в Волго-Уралье в эпоху раннего голоцена (краниологические материалы мезолита - бронзового века). Самара: СГСПУ, 2017. 368 с.

4. Балабанова М.А. Катакомбная культура ВолгоДонского междуречья по антропологическим данным // Материалы III междунар. Нижневолжской археологической конф. Астрахань: Астраханский университет, 2010. С. 42-50.
5. Казарницкий А.А. Палеоантропология эпохи бронзы степной полосы юга Восточной Европы: автореф. дис. ... канд. ист. наук: 03.03.02. СПб., 2011. $24 \mathrm{c}$.

6. Казарницкий А.А. Население Азово-Прикаспийских степей в эпоху бронзы (антропологический очерк). СПб.: Наука, 2012. 264 с.

7. Батиева Е.Ф. К вопросу об искусственной деформации черепа на нижнем Дону в эпоху средней бронзы // Актуальные направления антропологии: сб., посв. юбилею академика РАН Т.И. Алексеевой / отв. ред. А.П. Бужилова, М.В. Добровольская, М.Б. Медникова. М.: Изд-во ИА РАН, 2008. С. 26-33.

8. Перерва Е.В. Рентгенологическое исследование деформированных черепов эпохи средней бронзы с территории Нижнего Поволжья (палеопатологический аспект) // Вестник Волгоградского государственного университета. Серия 4. История. Регионоведение. Международные отношения. 2013. № 2 (24). C. 7-19.

9. Шепель Е.А. О некоторых особенностях серии черепов из погребений катакомбной культуры бассейна Северского Донца // Проблемы эпохи бронзы Юга Восточной Европы: тез. докл. конф. Донецк, 1979. C. 52-53.

10. Шепель Е.А. Население бассейна Северского Донца в эпоху энеолита-бронзы по антропологическим данным: автореф. дис. ... канд. ист. наук. Киев, 1985. 18 c.

11. Алексеев В.П. Население эпохи бронзы на Среднем Дону (краниология) // Курганы эпохи бронзы Среднего Дона «Павловский могильник» / А.П. Синюк. Воронеж: Изд-во Воронежского университета, 1983. С. 183-191.

12. Добровольская М.В. Искусственная деформация головы у носителей традиций среднедонской катакомбной археологической культуры (по материалам Первого Власовского могильника) // Искусственная деформация головы человека в прошлом Евразии. OPUS: Междисциплинарные исследования в археологии: сб. статей. Вып. 5. М.: Изд-во ИА PAH, 2006. C. 37-46.

13. Шевченко А.В. Краниологические материалы из могильников эпохи бронзы Калмыкии // Микроэволюционные процессы в человеческих популяциях. СПб.: МАЭ РАН, 2009. С. 235-267.

14. Гинзбург В.В. Этногенетические связи древнего населения Сталинградского Заволжья (По материалам Калиновского могильника) // МИА. М.; Л.: Изд-во АН СССР, 1959. № 60. С. 524-594.

15. Фирштейн Б.В. Антропологическая характеристика населения Нижнего Поволжья в эпоху бронзы: (По материалам раскопок в Волгоградской и Саратовской областях и в Калмыцкой АССР) // Памятники эпохи бронзы юга Европейской части СССР. Киев: Наук. думка, 1967. С. 100-140.

16. Жиров Е.В. Об искусственной деформации головы // КСИИМК. Вып. VIII. М.-Л.: Изд-во АН СССР, 1940. С. 81-88.

17. Гиппократ. О воздухе, водах и местностях // Избранные книги. Пер. В.И. Руднева. М.: Сварог, 1994. С. 279-306. 
18. Страбон. География: в 17 кн. / пер., вст. ст. и коммент. Г.А. Стратановского. М.: Ладомир, 1994. 944 с.

19. Макдиси. Извлечения из «Асхои Ат-Такасим Фи-ма'рифат Ал-Акалим» // Материалы по истории туркмен и Туркмении. Арабские и персидские источники. Т. I, ч. 1. VII-XV вв. М.-Л.: Изд-во АН СCCР, 1939. С. 166-208.

20. Якут. Извлечения из «Китаб Му' ДжабалБулдан Якут» // Материалы по истории туркмен и Туркмении. Арабские и персидские источники. VIIXV вв. М.-Л.: Изд-во АН СССР, 1939. Т. І. С. 409-438.

21. Вега Г. История государства инков [Электронный ресурс] // Восточная литература. - http://vostlit. info/Texts/rus14/Vega/pred.phtml.

22. Миклухо-Маклай Н.Н. Собрание сочинений в 6 томах. Статьи и материалы по антропологии и этнографии народов Океании (Новая Гвинея). Т. 3. М.: Наука, 1993. 414 с.

23. Уитлок Р. Майя: быт, религия, культура / пер. О.М. Федяев. Центрполиграф, 2005. 191 с.

24. Леббок Дж. Доисторические времена или первобытная эпоха человечества. М.: Типография А.И. Мамонтова, 1876. 491 с.

25. Хаген В.В. Ацтеки, майя, инки. Великие царства древней Америки / пер. И.А. Николаенко. М.: Вече, 2004. 464 c.

26. Dingwall E.J. Artificial Cranial Deformation. A Contribution to the Study of Ethnic Mutilations. London: John Bale, Sons and Danielsson, 1931. 303 p.

27. Ozbek M. Cranial Deformation in Subadult Sample From Değirmentepe (Chalcolit, Turkey) // American Journal of Physical Anthropology. 2001. Vol. 115. № 3. P. 238-243.

28. Ubelaker D.H. Human Skeletal Remains. Excavation, Analesis, Interpretation. Chicago: Adline Publishing company, 1978. $116 \mathrm{p}$.

29. Artificial cranial deformation [El. resource] // https://everipedia.org/wiki/Artificial_cranial_deformation.

30. Higher Human Forms: Skull Elongation [El. resource] // https://stufftoblowyourmind.com/blogs/higherhuman-forms-skull-elongation.htm.

\section{ANTHROPOLOGICAL ASPECT
OF THE ARTIFICIAL SKULL DEFORMATION CUSTOM \\ ANTHROPOLOGICAL ASPECT
OF THE ARTIFICIAL SKULL DEFORMATION CUSTOM AMONG THE MIDDLE BRONZE AGE POPULATION OF THE LOWER VOLGA REGION} (C) 2018

Balabanova Mariya Afanasievna, doctor of historical sciences, professor of Russian and Foreign History and Archeology Department Volgograd State University (Volgograd, Russian Federation) н. І. М.: Высшая школа, 1996. 463 с.

32. Балабанова М.A. О древних макрокефалов Восточной Европы // OPUS: Междисциплинарные исследования в археологии: сб. статей. Вып. 3. М.: Изд-во ИА РАН, 2004. С. 171-187.

33. Frieß M., Baylac M. Exploring artificial cranial deformation using elliptic Fourier analysis of procrustes aligned outlines // American Journal of Physical Anthropology. 2003. Vol. 122. P. 11-22.

34. Геннеп А. Обряды перехода. Систематическое изучение обрядов. М.: Восточная литература, 1999. $198 \mathrm{c}$

35. Лич Э. Культура и коммуникация: Логика взаимосвязи символов. К использованию структурного анализа в социальной антропологии. М.: Восточная литература РАН, 2001. 142 с.

36. Romero-Vargas S., Ruiz-Sandoval J.L., Sotomayor-Gonzalez A., Revuelta-Gutierrez R., Celis-Lopez M.A., Gomez-Amador J.L., Garcia-Gonzalez U., Lopez-Serna R., Garcia-Navarro V., Mendez-Rosito D., Correa-Correa V., Gomez-Llata S. A look at Mayan artificial cranial deformation practices: morphological and cultural aspects // Neurosurg Focus. Vol. 29 (6). December 2010.

37. Ayer A., Campbell A., Appleboom G., Hwang B.Y., McDowell M., Piazza M. et al. The sociopolitical history and physiological underpinnings of skull deformation // Neurosurg Focus. Vol. 29 (6). December 2010.

38. Истомин А.А. Салиши // Народы и религии мира. Энциклопедия. М.: БРЭ, 1999. С. 464-466.

39. Истомин А.А. Чинук // Народы и религии мира. Энциклопедия. М.: БРЭ, 1999. С. 627.

Статья публикуется при поддержке гранта РФФИ, «Население степного пространства междуречья Дона и Волги раннего и среднего периодов эпохи бронзы: демографический и антропологический состав, межпопуляционные связи, морфогенетический тренд» № 18-09-00309.

Abstract. This paper reviews an anthropological aspect of the artificial skull deformation which was practiced by
tribes of catacomb cultural-historical community of the Middle Bronze Age of the Lower Volga region and adjacent territories. Craniological series, numbering 207 skulls, was checked for the presence of deformation traces. 81 skulls had the traces of deformation, which is $35,2 \%$ of the total number. On average, the percentage of deformed skulls in some burial grounds of the catacomb culture of the Volgograd Region is about 17,0\%, but there are a few burial grounds in craniological series where deformed skulls are absent. The type of deformation is identified as annular and frontal-occipital. The analysis of anthropological works of Russian and foreign authors as well as written sources allows to agree with the idea of A.V. Shevchenko that the custom of the skull deformation among the tribes of catacomb cultural-historical community penetrated through the cultural centers of Western Asia. The comparison of deformed and unstrained series of skulls showed that only signs of the cerebral box undergo a change under the influence of the deforming structure in most cases. The deforming effect of the structure on facial features is very weak. When the process of pressure is completed, the skull acquires a tower shape or a shape of a high cone.

Keywords: catacomb cultural-historical community; premeditated artificial skull deformation; tower shape; frontal-occipital type of deformation; series; craniological features; Volga-Don interfluves; Kalmykia; morphological complex; cultural center of Western Asia. 